\title{
Variation detection and respondents' feedback: the cause, effect, and solution of oil spills
}

\author{
Ayodele Sunday Tologbonse* and Esther Oluwafunmilayo Makinde \\ Laboratory for Geospatial Research, Department of Surveying and Geoinformatics, Faculty \\ of Engineering, University of Lagos, Akoka Lagos State, Nigeria \\ ${ }^{*}$ Corresponding author: ayotologbonse@yahoo.com
}

\begin{abstract}
Centred on occurrences of pipeline explosion and oil spills in a host community; a supervised classification technique, of land use/land cover variation detection was carried-out, with Landsat imageries of three time intervals, to determine the percentage of variation between the time intervals. Also carried-out, was a random sampling of questionnaires; dispatch to acquire respondents' feedback. It addressed respondents' demographic and social-economic composition of the sample population, the perception on the cause and the impact, and the effect of the oil spill and finally considered the possible solutions. Information was subjected to descriptive analysis and an F-test statistical analysis in a $95 \%$ confidence interval. Reports showed that land use/land cover classification had undergone series of percentage variation within the time interval considered, indicating 'remarks' of a rise or a decline. While, the measure of insecurity (of about $36.7 \%$ ) is a prevailing element to the unceasing attack on oil pipelines and only a sustaining security measure (of about $40.8 \%$ ) will evidently pave a wayout. Wherefore advocating for community based policing, and a comprehensive technological sensor system, for monitoring of oil pipelines/facilities across the Nation.
\end{abstract}

Keywords: land use/land cover variation; respondents' feedback; test hypothesis.

\section{Introduction}

Over the years, the amount of oil produced and transported between points of production, processing and distribution or export terminals has greatly increased as the demand of and dependence on oil increased. It has also been observed that thousands of barrels of oil have been spilled into the environment through storage facilities disaster and mainly oil pipelines in Nigeria [8].

\subsection{Nigeria's oil economy}

Nigeria joined the league of oil producing nations on August 3rd, 1956 when oil was discovered in commercial quantities and in Africa today, it ranks as the leading oil and gas producer of all time [16]. It's the eleventh largest in the world [8].

Nigeria is the most populous nation in Africa with four hundred and forty million peoples as declared in the National Census in 2006. The attending of oil in commercial quantities in Nigeria, signalled the beginning of a profound transformation of Nigeria's political and economic landscape [16].

The strength of Nigeria's economy is the Petroleum sector, contributing about $90.0 \%$ of the nation's foreign exchange earnings and about $25.0 \%$ of the Gross Domestic Products. A significant proportion of the Nation's oil is produced onshore and is subsequently transported by pipelines [8] and the pipelines security has become a great challenge to the Nation, especially to the several host community harbouring such National assert. As it is well-known, energy 
plays a strong role in the economic, socio-political and environmental spheres of every nation and its importance can be seen in every facet of life and energy generation is largely dependent on petroleum products [13], although there is some contribution from hydropower, biomass and coal. According to [2], petroleum consumption has been on the increase in Nigeria since the early 1980s. This upward trend is evidenced in the energy consumption figures of 2006, 2007 and 2011 where petroleum products represents $53.0 \%, 67.3 \%$, and $68.5 \%$ in that order of the total energy consumed in the nation [7].

\subsection{Societal effects of oil spills}

The Nation has suffered the negative environmental effects of oil development ever since its discovery. In recent times, the development of the Nation's oil industry, combined with a population increase and a lack of implementation of environmental regulations has led to numerous self-inflicted damage to its environment [4].

Meanwhile, the occurrence of oil spill is due to a number of causes which include the following: corrosion of pipelines, sabotage and oil production operations [5]. Sabotage and oil siphoning has become a leading cause of oil spills in Nigeria [18] and being a major issue, as well contributed to further ecological degradation [5].

According to [11] damaged oil pipelines may go undetected for days, and repair takes even longer period. As a result oil tapping has become a big business, with the stolen oil swiftly making its way into the black market.

The grounds of pipeline damage and leakage can differ greatly varying from material failings and pipe corrosion to ground erosion, tectonic movements on the sea bottom and contact with ship anchors and bottom trawls particularly in the offshore operations while pipeline vandalization is observed as the significant cause of pipeline damage onshore in Nigeria [8]. This dangerous act of vandalization has led to several incidences of oil spill damaging vital national asserts and the ecosystem at large. Experience has shown that oil spill into the environment holds negative consequences, such as the problem of air pollution and vegetation loss; including aquatic habitat shrinkage and depleting of the soil nutrient component [8].

Whatever the angle oil spills is viewed, its outcome is an evidential threat to human health including hazardous effects on lands, water bodies, and vegetation's, swamps, marine environs in the affected host communities in Nigeria [12].

Key oil spills has attracted international attention and created awareness due to the associated ecological, human and conservational risk and damage that result from such spills. The common causes of oil spills are oil blowouts from the flow stations, equipment failure, and leakages from aged and corroded network of the pipelines, operational disaster, maintenance blunder, sabotage, bunkering and oil theft operations [12] and meanwhile, the well-endowed ecological resources are destroyed. In reaction to this [14] noted that, the Petroleum Act and the Oil Pipeline Act demands that affected residents be compensated for all intangible sociocultural and health environmental assets lost and market related real estate (for example: land, buildings, plant and machinery, severance, injurious affection, disturbance) to mention but a few [6]. Well-known, is the lack of enactment of these laws in protecting the environs and its populace. Ultimately, these incidences continue to reoccur and there effects are well patent in the society. 


\subsection{Variation detection technique}

Land use/land cover variation is one of the major driving powers of international conservational change, and central to the sustainable development debate and it adds to the main challenges that impact the original landscape [15]. Report [23] showed that, these variations, brings drastic impact on the physical and social environments which have been researches central point of reference. These spam around its impact on the capability of natural systems to support livelihood [25], biodiversity [17], soil degradation [26], and water quality, land and air resources, ecosystem and climate [15].

Furthermore, [1] explained that, the land use/land cover variation of a region is the result of relationship of both natural and socio- economic factors. Issues of Land use/land cover and its effect on ecological sustainability and human wellbeing has become of great worry all over the world. Variations in the land use/land cover arrays impact significantly on local and global environmental conditions as well as economic and social wellbeing. Understanding how the arrays are influence by these factors would provide new proportions to policy making and public policy assessment.

Variation detection is the method of determining differences in the state of an object or entity, phenomenon or occurrence by observing it at different epochs or times. It's an important procedure in monitoring and managing natural resources and urban change. These provide quantitative assessment of the spatial range of the Area of Interest (AOI). Meanwhile, the variation detection is described in four important categories; detecting the variations that have occurred, identifying the nature of variation, measuring the range to the variation degree, and analysing the spatial range of variation $[1]$.

\section{Procedure}

A geospatial technique was used to analyse the classification variation in determine the effect of oil pollution to communal life, the environment and it's asserts. And to proof the outcomes that surrounds oil pollution through the medium of respondents' feedback. Wherefore, the procedure undertaking in achieving the needed outcome is outlined accordingly.

\subsection{Land use/land cover variation}

The supervised classification method was used to identify land use/land cover classes of built/developed region, vegetation/forest region, bare/undeveloped region and water/river region. This well describes the variation that emanated as a result of the Landsat imagery time intervals considered. Meanwhile, the spatial range of each class was calculated in Square kilometre and presented in percentage values (\%).

The Percentage variation to determine the 'variation degree' was calculated [20].

$$
P=\{(A-B) / B\} \times 100
$$

where

$P=$ percentage variation of land use/land cover for a particular purpose within a specified time interval.

Geoinformatics FCE CTU 17(1), 2018 
$A=$ region under that particular purpose of land use/land cover after the time interval.

$B=$ region under that particular purpose of land use/land cover before the time interval

\subsection{Classification accuracy analysis}

Accuracy analysis reports the supervised land use/land cover classification of the time intervals of the Landsat imagery under consideration (2011, 2014 and 2015). It's a procedure for quantifying how good a job was done by a classifier and how accurate classification was.

Accuracy analysis is an important part of classification. It compares the classification product with a reference data that is believed to reflect the true land use/land cover accurately. The source of reference data was the Landsat imagery. Figure 1, showed a print screen of the accuracy analysis.

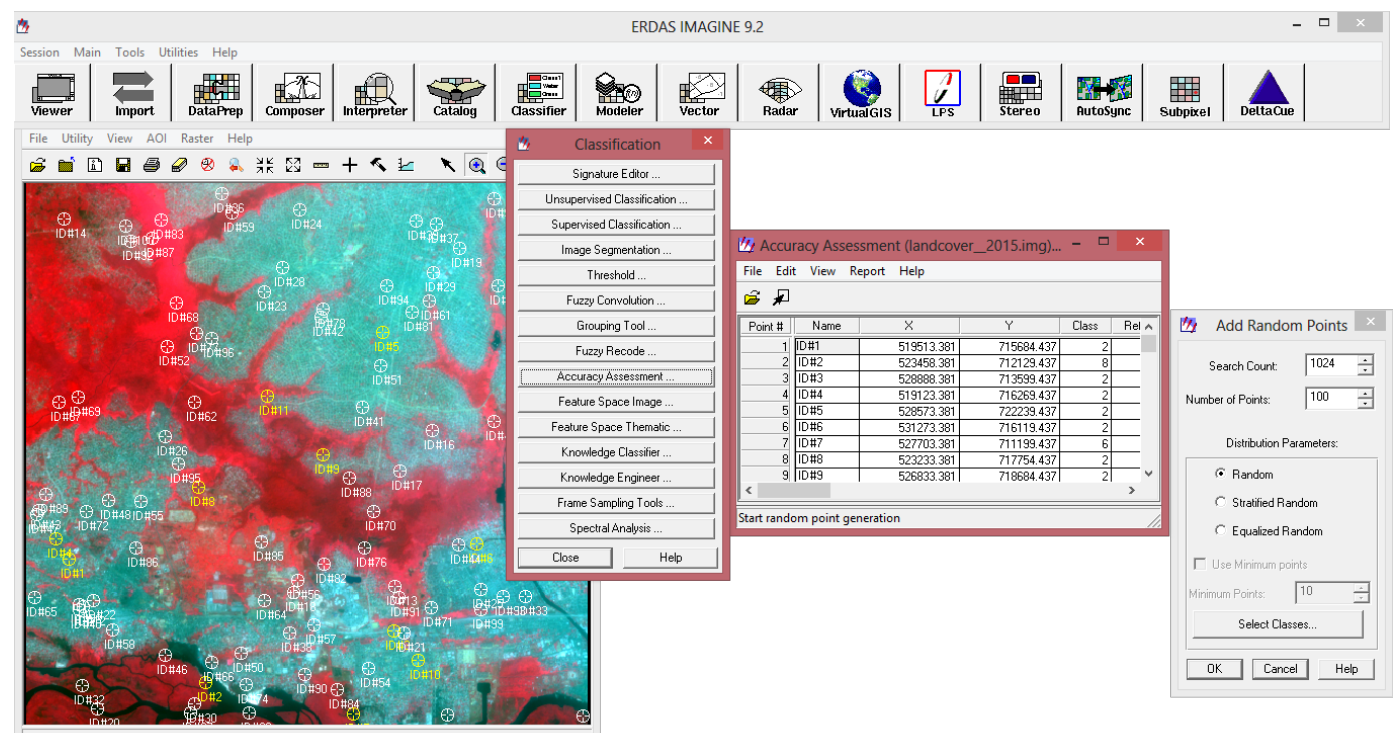

Figure 1: Print screen views of accuracy analysis procedure on ERDAS imagine.

\subsection{Respondents' feedback}

The procedures undertaken include:

$$
\begin{aligned}
\text { Sample size population } & =\{(T N / P S)\} \times 100 \% \\
& =\{(147 / 609.173)\} \times 100 \% \\
& =(0.024 \%)
\end{aligned}
$$

where

$T N=$ total number of questionnaires.

$P S=$ population size of Ojo local government area, according to the national census of 2006 in Nigeria.

Geoinformatics FCE CTU 17(1), 2018 
The total number of 147 questionnaires was randomly sampled in the host community. A total of twenty questions was outlined, four sections in all, with the appropriate question for each section. The open ended option was adopted which helped streamline respondents' thoughts. Question boarders on the demographic and social-economic composition of the sample population, perception on the cause of the oil spill, perception on the effect of the oil spill, and finally considered the possible solutions to the menace. The questions were aroused from perceived issues, reconnaissance and information gathered, and consultation from a number people within and withal the host community.

\subsection{Test hypothesis}

The information of the respondents' feedback was subjected to:

Descriptive analysis, and

F-test statistical analysis.

\section{Analysis and discussion}

This identifies in detail the intended results analysis, presentations, and discussion.

\subsection{Variation report}

The analysis identified the 'variation degree' that occurred at the time intervals considered. The interval checks carried out were from 2011 to 2014 and 2014 to 2015.

This were necessary to ascertain the differences the land use/land cover had undergone in the course of such time and to reference the impact of oil spills over such time intervals, as it affects the "subject matter" in line with the host community and environs. The variation analyses are as follows in Table 1, Figure 2 and Figure 3.

Table 1: Variation degree analysis report of the time intervals.

\begin{tabular}{|c|c|c|c|c|c|c|c|}
\hline $\begin{array}{c}\text { Land use } \\
\text { / Land cover }\end{array}$ & 2011 & 2014 & 2015 & \multicolumn{2}{|c|}{2011 to 2014} & \multicolumn{2}{|c|}{2014 to 2015 } \\
\cline { 2 - 8 } & $(\%)$ & $(\%)$ & $(\%)$ & $(\%)$ & Remarks & $(\%)$ & Remarks \\
\hline $\begin{array}{c}\text { Built } \\
\text { / Developed region }\end{array}$ & 44.0 & 64.0 & 69.0 & $\mathbf{4 5 . 0}$ & A rise & $\mathbf{+ 8 . 0}$ & A rise \\
\hline $\begin{array}{c}\text { Vegetation } \\
\text { / Forest region }\end{array}$ & 32.0 & 29.0 & 26.0 & $\mathbf{- 9 . 0}$ & $\mathbf{A}$ fall & $\mathbf{- 1 0 . 0}$ & A fall \\
\hline $\begin{array}{c}\text { Bare } \\
\text { / Undeveloped region }\end{array}$ & 15.0 & 4.0 & 2.0 & $\mathbf{- 7 3 . 0}$ & $\mathbf{A}$ fall & $\mathbf{- 5 0 . 0}$ & A fall \\
\hline $\begin{array}{c}\text { Water } \\
\text { River region }\end{array}$ & 9.0 & 2.7 & 2.5 & $\mathbf{- 6 7 . 0}$ & $\mathbf{A}$ fall & $\mathbf{- 7 . 4}$ & A fall \\
\hline
\end{tabular}

\subsection{Accuracy report}

The analysis showed the Accuracy Totals (AT), the Overall Classification Accuracy (OCA) and the Overall Kappa Statistics (OKS) for each of the land use/land cover classification. 


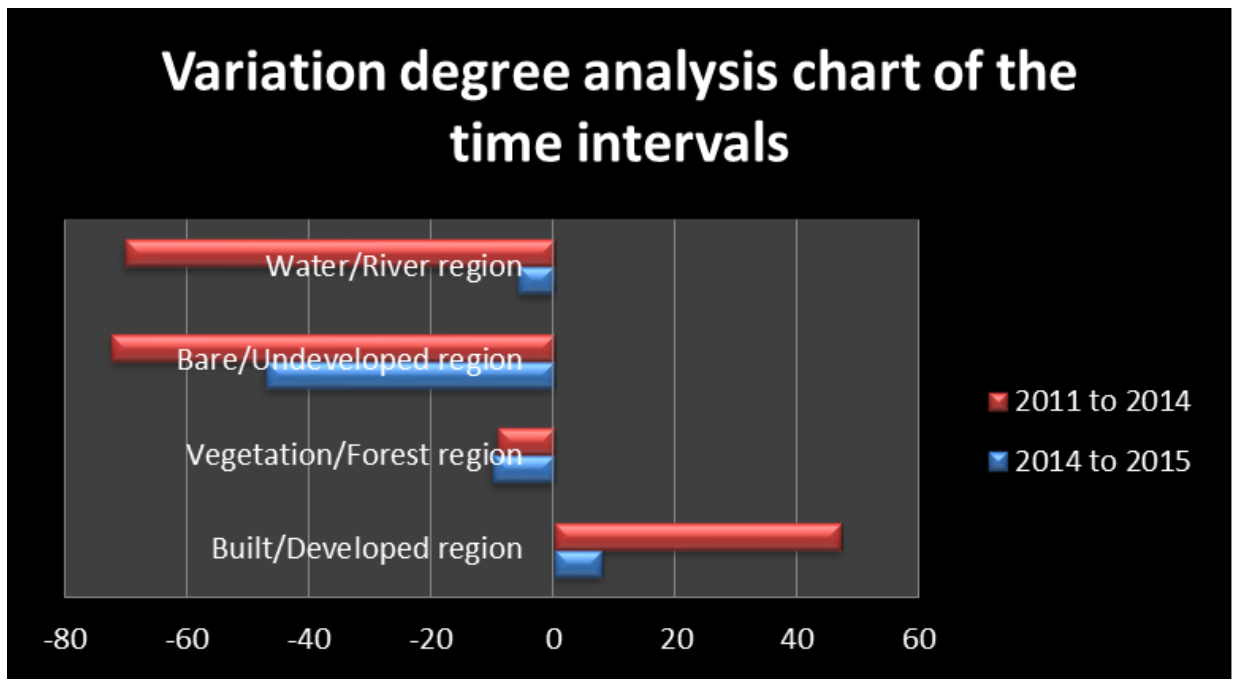

Figure 2: Chart showing a broader view of the 'variation degree' of the time intervals.

The overall classification accuracy for 2011 was $88.0 \%$, 2014 was $84.0 \%$ and 2015 was $83.0 \%$ respectively.

The table presented with columns of Class Name (CN), Reference Totals (RT), Classified Totals (CT), Number Correct (NC), Producers Accuracy (PA) and Users Accuracy (UA). The analysis was as follows in Table 2.

Table 2: Land use/land cover accuracy analysis report.

\begin{tabular}{|c|c|c|c|c|c|c|c|c|c|c|c|c|c|c|c|}
\hline \multicolumn{16}{|c|}{ AT } \\
\hline \multirow{2}{*}{$\mathrm{CN}$} & \multicolumn{5}{|c|}{2011} & \multicolumn{5}{|c|}{2014} & \multicolumn{5}{|c|}{2015} \\
\hline & RT & CT & NC & $\begin{array}{l}\mathrm{PA} \\
(\%)\end{array}$ & $\begin{array}{l}\mathrm{UA} \\
(\%)\end{array}$ & RT & $\mathrm{CT}$ & $\mathrm{NC}$ & $\begin{array}{l}\mathrm{PA} \\
(\%)\end{array}$ & $\begin{array}{l}\text { UA } \\
(\%)\end{array}$ & RT & UA & NC & $\begin{array}{l}\mathrm{PA} \\
(\%)\end{array}$ & $\begin{array}{l}\text { UA } \\
(\%)\end{array}$ \\
\hline $\begin{array}{c}\text { Built } \\
\text { / Develped region }\end{array}$ & 51 & 43 & 43 & 84 & 100 & 48 & 58 & 47 & 98 & 81 & 55 & 71 & 55 & 100 & 77 \\
\hline $\begin{array}{l}\text { Vegetation } \\
\text { / Forest region }\end{array}$ & 37 & 33 & 33 & 89 & 100 & 44 & 31 & 31 & 70 & 100 & 37 & 21 & 21 & 57 & 100 \\
\hline $\begin{array}{c}\text { Bare } \\
\text { / Undeveloped region }\end{array}$ & 4 & 15 & 4 & 100 & 27 & 4 & 8 & 3 & 75 & 38 & 2 & 3 & 2 & 100 & 67 \\
\hline $\begin{array}{c}\text { Water } \\
\text { / River region }\end{array}$ & 8 & 9 & 8 & 100 & 89 & 4 & 3 & 3 & 75 & 100 & 6 & 5 & 5 & 83 & 100 \\
\hline Total & 100 & 100 & 88 & & & 100 & 100 & 84 & & & 100 & 100 & 83 & & \\
\hline OCA & \multicolumn{5}{|c|}{$=88.0 \%$} & \multicolumn{5}{|c|}{$=84.0 \%$} & \multicolumn{5}{|c|}{$=83.0 \%$} \\
\hline OKS & \multicolumn{5}{|c|}{$=0.8141$} & \multicolumn{5}{|c|}{$=0.7245$} & \multicolumn{5}{|c|}{$=0.6782$} \\
\hline
\end{tabular}

\subsection{Feedback report}

Analysis of respondents' bio-data recorded the following. This is the demographic and socialeconomic distributions of the respondents. The background information of respondents was deemed necessary. The ability of the respondents to give satisfactory information on the study variables greatly depends on their background. The background information of respondents 


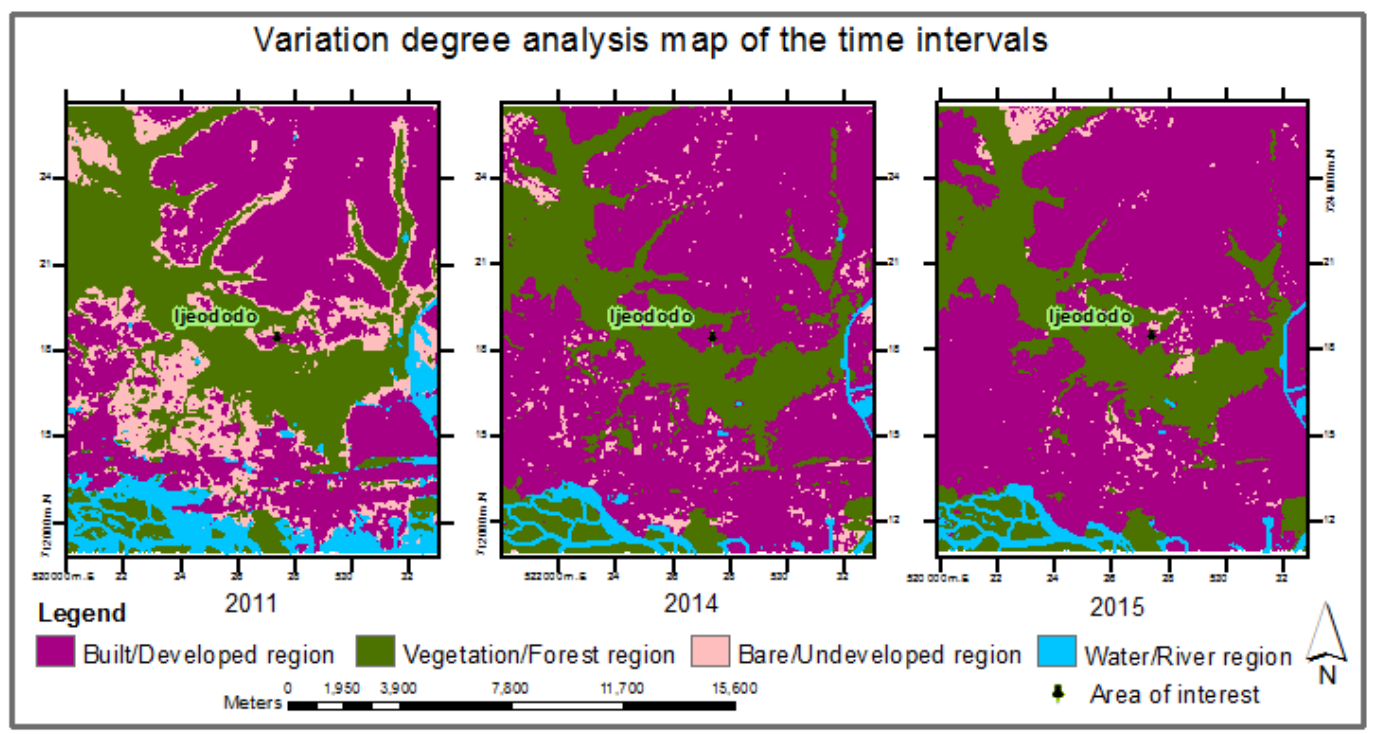

Figure 3: Map showing an analysis of the 'variation degree' of the time intervals.

solicited data on the samples and it's presented in categorizes of: sex, age, education levels, marital status, income level and occupation (Table 3).

It indicated $57.8 \%$ out of the total 147 respondents were male, while, $42.2 \%$ were female. It showed that, $42.2 \%$ were between the age of 15 and $25,30.6 \% 26$ and $36,19.0 \% 37$ and 47 , and $8.2 \%$ were 47 years and above.

Meanwhile, the married were of $51.0 \%$, single were $40.1 \%, 4.1 \%$ were divorce and $4.8 \%$ were widows/widower. $48.3 \%$ were into trading/business, $4.1 \%$ were farming/hunting, $1.4 \%$ was of the fishing occupation, and $8.8 \%$ were civil servant, while, $37.4 \%$ did not express their opinions.

Likewise, $13.6 \%$ of respondents' earn between 5000-10000, 6.1\% earn between 10000-15000, and $22.4 \%$ earn between 15000-20000. But, 34.7\% earn an income of 20000 and above. Responses of about $23.1 \%$ were not indicated. Then, $7.0 \%$ of the respondents' had qualification of primary school, $38.8 \%$ secondary school, and $14.3 \%$ tertiary respectively. While $46.3 \%$ were of other categories.

Analysis of respondents' perceived cause of oil spill recorded the following. This is the perception of respondents on the cause of oil spill. These delve in understanding the view of the respondents as it's meant to assess the effect on the host community. The results presented reveals perceived cause, categorized into: the meaning of oil spill, the incident of oil spill if any, the time it occur, and the perceived cause (s) (Tables 4).

It showed that only $89.1 \%$ could give a 'Yes' assent to the incident of oil spill in the community, far above the $6.1 \%$ who said 'No', while, $2.7 \%$ were not aware. Likewise, $51.7 \%$ of the respondents' believed the major cause of the oil spill was pipeline vandalization, $17.0 \%$ pipeline leakage, $2.7 \%$ went with leakage/spill from tanker, and $17.7 \%$ poor maintenance procedure.

Basically, procedures from the respondents' feedback gave a positive acknowledgement of 
Table 3: Respondents bio-data

\begin{tabular}{|c|c|c|c|}
\hline Variable & Options & Frequency (F) & Percent (\%) \\
\hline \multirow[t]{2}{*}{ Sex } & Male & 85 & 57.8 \\
\hline & Female & 62 & 42.2 \\
\hline \multirow[t]{4}{*}{ Age } & $15-25$ & 62 & 42.2 \\
\hline & $26-36$ & 45 & 30.6 \\
\hline & $37-47$ & 28 & 19.0 \\
\hline & Above & 12 & 8.2 \\
\hline \multirow[t]{4}{*}{ Marital statute } & Married & 75 & 51.0 \\
\hline & Sinlge & 59 & 40.1 \\
\hline & Divorced & 6 & 4.1 \\
\hline & Widow/Widower & 7 & 4.8 \\
\hline \multirow[t]{5}{*}{ Occupation } & Trading/Business & 71 & 48.3 \\
\hline & Farming/Hunting & 6 & 4.1 \\
\hline & Fishing & 2 & 1.4 \\
\hline & Civil Servant & 13 & 8.8 \\
\hline & Nil & 55 & 37.4 \\
\hline \multirow[t]{5}{*}{ Income } & $5000-10000$ & 20 & 13.6 \\
\hline & $10000-15000$ & 9 & 6.1 \\
\hline & $15000-20000$ & 33 & 22.4 \\
\hline & 20000 \& Above & 51 & 34.7 \\
\hline & Nil & 34 & 23.1 \\
\hline \multirow[t]{4}{*}{ Education } & Primary & 1 & 0.7 \\
\hline & Secondary & 57 & 38.8 \\
\hline & Tertiary & 21 & 14.3 \\
\hline & Other Categories & 68 & 46.3 \\
\hline \multicolumn{2}{|c|}{ Total of each variable } & 147 & 100 \\
\hline
\end{tabular}

the incident of oil pollution and its main cause. This was significant and pivotal to the development and analysis of this research paper, given a broader view to its content and results. Such outcomes, helped to further boast upcoming contents, results, reports and analyses as the processes develops.

Analysis of respondents' perceived effect of oil spill recorded the following. This is the respondent's perceived effect of oil spill. The information of respondents was deemed necessary because the ability of the respondents to give satisfactory information on the study variables is of great importance to this paper, in analysing situation that surrounds the reasons for hypotheses and the presented categorizes which is: the degree of effect, areas it has affected, and the level of occurrence of disease, if there have been any (Table 5).

Therefore, it revealed a $53.7 \%$ of the respondent identifying the impact of oil pollution affecting the air, water, and land. This resulted also to neglect by other communities and the government, given a $1.4 \%$ percentage value. Environmental pollution of about $34.0 \%$ was recorded, leading to series of features like; un-conducive environment for the populace $(26.5 \%)$, negative impact on health and life $(12.9 \%)$, loss of livelihood $(6.1 \%)$, insecurity increase $(36.7 \%)$, and several health issues $(19.7 \%)$. 
Table 4: Respondents perceived cause of oil spill.

\begin{tabular}{|c|c|c|c|}
\hline \multicolumn{2}{|c|}{$\begin{array}{c}\text { Has there been any incident of } \\
\text { soil spill in the host community? }\end{array}$} & \multicolumn{2}{|c|}{$\begin{array}{c}\text { What do you think is the cause of the oil } \\
\text { spill? }\end{array}$} \\
\hline Options & $\begin{array}{c}\text { Response } \\
(\%)\end{array}$ & Options & $\begin{array}{c}\text { Response } \\
(\%)\end{array}$ \\
\hline \hline Yes, there has been & $\mathbf{8 9 . 1}$ & Pipeline vandalization & $\mathbf{5 1 . 7}$ \\
\hline No, there hasn't & $\mathbf{6 . 1}$ & Pipeline leakage & $\mathbf{1 7 . 0}$ \\
\hline Really not sure & $\mathbf{2 . 7}$ & Leakage/spill from tanker & $\mathbf{2 . 7}$ \\
\cline { 2 - 4 } & & Poor maintenance procedure & $\mathbf{1 7 . 7}$ \\
\cline { 2 - 4 }
\end{tabular}

Table 5: Respondents perceived effects of oil spill.

\begin{tabular}{|c|c|}
\hline $\begin{array}{c}\text { How has oil spill affected } \\
\text { the host community? }\end{array}$ & $\begin{array}{c}\text { What can be said about the effect in } \\
\text { the host community? }\end{array}$ \\
\hline Options & Options \\
Response (\%) & Response (\%) \\
\hline \hline It has affected the air, water and land, & Loss of jobs \\
thereby resulting in hardship & $\mathbf{6 . 1}$ \\
$\mathbf{5 3 . 7}$ & Insecurity \\
It has brought neglect by other communities & $\mathbf{3 6 . 7}$ \\
$\mathbf{1 . 4}$ & Health issues \\
Polluting the environment making it & $\mathbf{1 9 . 7}$ \\
not conducive for our children to play & Environmental pollution \\
$\mathbf{2 6 . 5}$ & $\mathbf{3 4 . 0}$ \\
It has negatively affected our health and life & \\
$\mathbf{1 2 . 9}$ & \\
\hline
\end{tabular}

Analysis of respondents' perceived solution of oil spill recorded the following. This is the perceived solution of the respondents to the causes and effects of oil spill. The breakdown on how oil spill could be tackled is very vital to this paper and researches at large. It also aided to assess the impact oil spill posed in entirety. The perceived solution information from the samples is presented in categorizes of; the inputs of individual, community, relevant authorities and the way-out in tackling the challenges.

In addition, the perceived solution of the respondents' to the causes and effects of oil spill, produced responses in Table 6. It indicated that amongst all viable solution (way-out) $40.8 \%$ of respondents' said security agent should be found guiding the entire pipeline effectively. By this response, $17 \%$ admonished the authorities to adopt a feasible plan for maintenance resolutions and $27.2 \%$ said by privatizing the sector it will bring for proper supervision.

Meanwhile, $15.0 \%$ resolve that, the community should be given the right to secure the pipelines, thus, bringing about employment opportunity to a line-up of unemployed youth. All this points are well effective and this adds to the ingredients' for a better policy standards in the oil sector of a Nation. 
Table 6: Respondents perceived solution of oil spill.

\begin{tabular}{|l|c|}
\hline \multicolumn{2}{|c|}{ What do you think is the solution (way-out)? } \\
\hline \multicolumn{1}{|c|}{ Options } & Response (\%) \\
\hline \hline Security agent should be found guiding all entire pipelines & $\mathbf{4 0 . 8}$ \\
\hline The authorities should adopted a plan for maintenance resolutions & $\mathbf{1 7 . 0}$ \\
\hline The government should privatize the sector for proper supervision & $\mathbf{2 7 . 2}$ \\
\hline $\begin{array}{l}\text { The host community should be given the right to secure the pipelines } \\
\text { thereby, bringing about employment }\end{array}$ & $\mathbf{1 5 . 0}$ \\
\hline
\end{tabular}

\subsection{Hypothesis report}

The hypothesis report showed an F-test statistical analysis. This analysis is referred to as a reliability analysis frequency test which showed the mean statistics and the confidence interval at $95.0 \%$. Five items of the research questions, which boarders on oil spill perceive causes, effects and solutions were identified and analysed.

The significance and correlation of the research questions were tested for. These are presented in Table 7 and 8 correspondingly. Therefore, the F-test hypothesis is as follows:

H0: The oil spill does not significantly affect the research area.

H1: The oil spill does significantly affect the research area.

Table 7 showed the mean statistics of the selected research questions of the respondents that concerns the cause; effect and solution of oil spill in the research area (that is, item 1, 2, 3, 4, and 5). The grand mean for the five items was 1.93 and the variance was 17.383 .

Table 7: Items mean statistics.

\begin{tabular}{|c|c|c|c|}
\hline Item & Research question & Mean & Std. deviation \\
\hline 1. & $\begin{array}{c}\text { Has there been any incident of oil spill in } \\
\text { the host community? }\end{array}$ & 1.04 & 0.189 \\
\hline 2. & $\begin{array}{l}\text { What do you think is the cause of the oil } \\
\text { spill? }\end{array}$ & 1.80 & 1.114 \\
\hline 3. & $\begin{array}{l}\text { How has oil spill affected the host } \\
\text { community? }\end{array}$ & 1.96 & 1.170 \\
\hline 4. & $\begin{array}{l}\text { What can be said about the effect in the } \\
\text { host community }\end{array}$ & 2.82 & 0.968 \\
\hline 5. & $\begin{array}{l}\text { What do you think is the solution } \\
\text { (way-out)? }\end{array}$ & 2.04 & 1.043 \\
\hline \multicolumn{4}{|r|}{4.169} \\
\hline
\end{tabular}

Table 8 described the output of the F-test statistics analysis and whether there is a statistically significant difference between the group means. It is seen that the significance level was 0.000 $(\mathrm{p}=0.000)$, which is below 0.05 , the acceptable allowance.

Hence the null hypothesis (H0) is rejected and the alternate hypothesis (H1) accepted. It 
Table 8: F-test statistical analysis on items.

\begin{tabular}{|c|c|c|c|c|c|c|c|c|}
\hline \multicolumn{2}{|c|}{ Item analysis } & $\begin{array}{l}\text { Sum of } \\
\text { Squares }\end{array}$ & $\mathrm{df}$ & & $\begin{array}{l}\text { ean } \\
\text { uare }\end{array}$ & \multicolumn{2}{|l|}{$\mathrm{F}$} & Sig. \\
\hline \multicolumn{2}{|c|}{$\begin{array}{l}\text { Between People } \\
\text { Within People }\end{array}$} & 469.351 & 135 & \multicolumn{2}{|c|}{3.477} & \multirow{2}{*}{\multicolumn{2}{|c|}{183.689}} & \multirow[b]{2}{*}{0.000} \\
\hline \multicolumn{2}{|c|}{ Between Items } & 219.259 & 4.0 & \multicolumn{2}{|c|}{54.815} & & & \\
\hline \multicolumn{2}{|c|}{ Residual } & 161.141 & 540 & \multicolumn{2}{|c|}{0.298} & & & \\
\hline \multicolumn{2}{|c|}{ Total } & 380.400 & 544 & \multicolumn{2}{|c|}{0.699} & & & \\
\hline \multicolumn{2}{|l|}{ Total } & 849.751 & 679 & \multicolumn{2}{|c|}{1.251} & & & \\
\hline & \multirow{2}{*}{$\begin{array}{l}\text { Intra class } \\
\text { Correlation }\end{array}$} & \multicolumn{3}{|c|}{$\begin{array}{c}\text { Confidence Interval } \\
95 \%\end{array}$} & \multicolumn{4}{|c|}{$\begin{array}{c}\text { F Test } \\
\text { with True Value } 0\end{array}$} \\
\hline & & $\begin{array}{l}\text { Lower } \\
\text { Bound }\end{array}$ & \multicolumn{2}{|c|}{$\begin{array}{l}\text { Upper } \\
\text { Bound }\end{array}$} & Value & df1 & df2 & Sig. \\
\hline Single Measures & 0.476 & 0.237 & \multicolumn{2}{|c|}{0.650} & 11.651 & 135 & 540 & 0.000 \\
\hline Average Measures & 0.820 & 0.608 & \multicolumn{2}{|c|}{0.903} & 11.651 & 135 & 540 & 0.000 \\
\hline
\end{tabular}

therefore, concludes that oil spill significantly affected the research area. $\mathrm{df}=$ degree of freedom. $\mathrm{F}$ = frequency.

\subsection{Discussion}

Analysis based on findings testifies to the fact that over time intervals, land use/land cover are affected either positively or negatively [1]. With respect to oil spills and its challenges, this gives a worrying trend to the subject matter. This had majorly impacted the environs and its ecosystem negatively.

Meanwhile, the results of the Landsat imageries used showed series of variation in percentage values of the entire land use/land cover classification (Table 1). Specifically, vegetation/forest and water/river had undergone series of declining changes from the time interval under consideration, which could be attributed to the impact of oil spill in the environment, notwithstanding other factors (Figure 2). In view of this, [10] had reported that oil spill affect vegetation, water and the impacts of small spills can send ripples into surrounding ecosystems and affect communities beyond the immediate spill area.

Clearly, the vegetation/forest, bare/undeveloped and water/river regions has the worst hit when compared to built/developed region; especially, the vegetation/forest region. Most were burnt off as result of oil spill fires and are gradually changed by light forest. Similar reports of [18], [20] and [21] testified to these specifics. Also, the analysis from water/river region showed a fall in the specifics within 2011 to 2014 by $67.0 \%$ and slight within 2014 to 2015 by $7.4 \%$. This could be as a result of its nature of movement which can credited to either natural or artificial means. This submission is in relation to [24] who stated that the loss could be attributed to the division of larger water bodies into lesser ones and/or reclaimed to have built-up edifices. These attest to the percentile rise in built/developed region and a fall in bare/undeveloped region, at both time interval of this report (Table 1). In view of this, the role of oil spill impact on the environment, and its land cover cannot be rule out. 
This poses a grave concern and it's of relevance of this research. The figures gave a broader analysis to the variation degrees (Figure 2 and 3); while, reports on respondents' feedback further discusses its role in the host community.

Consequently, the incidence of oil spill in different parts of the world had caused severe technical hitches and dangers to the environment. Some of the reasons were mentioned and analysed in this research paper. The cause of oil spill which include pipeline vandalization, pipeline leakage, leakage/spill from tanker and poor maintenance procedure. Emphasis on pipeline vandalization with $51.7 \%$ points to the fact that vandals explore this medium to siphon oil product for selfish interest (Table 4).

Statistical gathering indicated that some of the members of the community and environs do collaborate with vandals to siphon oil; same goes for some security personal meant to protect such facility. Such actions haven't always gone down well. Researches showed that scores of suspected pipeline vandals mostly lose their life by reason of explosion. For example, scores of dead vandals were recorded on 07 November, 2014 in Ijeododo community of Lagos. Similar event was reported at Ilado-community in Lagos recording deaths of more than 250 persons, which are far less than 1200 immediate deaths recorded at Jesse in the Niger Delta, Nigeria $[9,20]$. This findings suggested that either the pipeline were laid in such a manner that encourages easy vandalization or either the safety laws considered while laying the pipelines were not implemented and/or either the security measures put in place to protect oil facilities was a mirage. Despite these issues, recent experience in Nigeria had shown that the integrity and safety of these pipelines have been continually compromised by the activities of vandals and saboteurs. This vandals fracture the oil pipelines with the criminal intent of obtaining and appropriating petroleum products for commercial purposes or personal use [19].

Respondents' analyses further testified to the fact that pipeline vandalization is the major cause of oil spills, which often leads to fire outbreak. The assessment revealed that out of the $89.1 \%$ of respondents that acknowledged the incident of oil spills in the host community only $51.7 \%$ went for pipeline vandalization as the major cause and this out-ways other causes of oil spills on the environment including the least of all which was leakage/spill from tanker with $2.7 \%$. This findings identified is expected to solve impending challenges that spans-out of pipeline vandalization and oil spills incidence. These challenges could include economic losses, hazard to human health, increasing poverty level of the communities and reduced rate of community development. Environmental pollution, health issues and insecurity are part of the challenges. Also, assessment on the host community revealed that only $34.0 \%$ went for environmental pollution, $19.7 \%$ for health issues and $36.7 \%$ went for insecurity as an effect of oil spill. However, showing that oil spill could pollute the environment making it not conducive for human activities. This pollution which affects the air, water and land, mostly results to hardship and negatively hampering healthy living.

Moreover, facts gathered from the host community reported that the frequent oil pipeline explosion caused by vandals in the area, led to outage of electric power supply and its nonavailability goes for a very long period. This brought hardship and cost of operating other source of power like generators were weighty. The findings also revealed that in 2013 power outage went for seven months (May to December) and similar incident occurred in 2015.

Therefore, the presence of security around oil facilities and continuous implementation of the law by enforcement bodies in protecting the oil pipeline/facilities in Nigeria is of great 
significance. Its effectiveness could be community based policing which gives the community right to secure the pipelines thereby bringing about employment and reduce continuous attack. In a long run a comprehensive technological system to help monitor pipeline facilities across the Nation is encouraged. This agreed with [3], [20] and [21], which states that monitoring of infrastructures such as oil pipelines is better supported by wireless technologies and virtual machines.

\section{Conclusion}

The aim of this process was to outline the findings of the weighty effects of oil pollution on communal life, land use/land cover classification, with additional proofs from respondents' feedback consequently. Substantially, all views as shown the impact of oil spill incidences from unlawful activities around oil pipeline/facilities, to its effect on the environment, humans and the ecosystem. The geospatial analysis of the classification also showed the level of changes that occurred within the time interval considered. At most, the ideals of safeguarding the Nations human, and natural assert (land, water, forest and vegetation) and man-made monuments (oil pipeline/facilities) in limiting the adverse effect of oil pollution are not negotiable.

This research paper put forwards its argument, and its advocating for the need of community based policing, and in a long run a comprehensive technological sensor system, to help monitor, oil pipeline/facilities across the Nation.

\section{Acknowledgements}

Our appreciation goes to the host community and the Department of Surveying and Geoinformatics, Faculty of Engineering, University of Lagos, Akoka, Lagos State, Nigeria for their support.

\section{Reference}

[1] Abiodun O, et al. "Land Use Change Analysis in Lagos State, Nigeria, from 1984 to 2005". In: FIG Working week, Marrakech Morocco (May 2011), TS09C - Spatial Information Processing II, 5142.

[2] Agusto and Co Limited. "Industry Report, Downstream Oil and Gas", 2008. URL: http: //s3.amazonaws.com/zanran_storage/proshareng.com/ContentPages/2461544354. pdf.

[3] Akhondi M et al "Applications of wireless sensor networks in the oil, gas and resources industries". In: Proceedings of the 24th IEEE International Conference on Advanced Information Networking and Applications (AINA '10), (April 2010), pp. 941-948, Perth, Australia. doi: 10.1109/AINA.2010.18.

[4] Akpofure E et al. "The Adverse Effects of Crude Oil Spills in the Niger Delta", 2000. URL: http://www.waado.org/environment/petrolpolution/oilspills_AdverseEffects. html.

[5] Anderson I. "Niger River Basin: Vision for Sustainable Development". The World Bank Washington D.C., 2005, pp. 1-131. 
[6] Bello V. Communities' Willingness to Pay for Protection. In: European Centre for Research Training and Development UK, 2015, pp. 67-76. http://www.eajournals.org.

[7] Energy Information Administration (EIA). "Annual energy review 2011". US Energy Information Administration, (September 2012).

[8] Eyo-Essien L. "Oil Spill Management in Nigeria: Challenges of Pipeline Vandalism in the Niger Delta Region of Nigeria". National Oil Spill Detection \& Response Agency (NOSDRA), Abuja-Nigeria, 2007.

[9] Fadeyibi I et al. "Burns and fire disasters from leaking petroleum pipes in Lagos, Nigeria: an 8-year experience", 2011. 37:145-52.

[10] Hess R and Kerr C. "A model to forecast the motion of oil on the sea". In: Proceedings of the Oil Spill Conference, 1979, pp. 653-663.

[11] Human Rights Watch. "The Price of Oil Retrieved" (May 2007). URL: http://www . hrw.org.

[12] Ite A et al. "Petroleum Exploration: Past and Present Environmental Issues in the Nigeria's Niger Delta". In: American Journal of Environmental Protection, 2013, pp. $78-90$.

[13] Iwayemi A. "Nigeria's dual energy problems: policy issues and challenges". In: International Association for Energy Economics, 31st IAEE International Conference, Istanbul, Turkey, (June 2008).

[14] Kalu I. "An Economic Contribution to Environmental Degradation Remediation of the Niger Delta". The Estate Surveyor and Valuer, 25 (1).

[15] Lambin E et al. "Are agricultural land-use models able to predict changes in land-use intensity"? In: Agriculture, Ecosystems and Environment, 2000, pp. 321-331. URL: http://dx.doi.org/10.1016/S0167-8809(00)00235-8.

[16] Legborsi S. "The Adverse Impacts of Oil Pollution on the Environment and Wellbeing of a Local Indigenous Community: The Experience of the Ogoni People of Nigeria", 2007. PFII/2007/WS.3/6 Original: English. Pg.2.

[17] Liu J and Ashton P. "FORMOSAIC: an individual-based spatially explicit model for simulating forest dynamics in landscape mosaics". In: Ecol. Modell, 106, 1998, pp. 177-200. URL: http://dx.doi.org/10.1016/S0304-3800(97)00191-9.

[18] Makinde E and Tologbonse A. "Oil Spill Assessment in Ijeododo Area of Lagos State, Nigeria Using Geospatial Techniques". In: Ethiopian Journal of Environmental Studies \& Management 10(4) (May 2017), pp. 427-442. ISSN: 1998-0507. URL: https://dx. doi.org/10.4314/ejesm.v10i4.1.

[19] Okoli C, and Orinya S. "Oil Pipeline Vandalism and Nigeria's National Security Federal University Lafia, Nigeria". In: Global Journal of Human Social Science Political Science. Global Journals Inc. (USA), 2013. Online ISSN: 2249-460x \& Print ISSN: 0975-587X.

[20] Omodanisi E. et al. "A multi-perspective view of the effects of a pipeline explosion in Nigeria". In: International Journal of Disaster Risk Reduction, 2013. URL: http: //dx.doi.org/10.1016/j.ijdrr.2013.11.002i. 
[21] Omodanisi E. "Resultant Land Use and Land Cover Change from Oil Spillage Using Remote Sensing and GIS". In: Research Journal of Applied Sciences, Engineering and Technology 6(11) (June 2013), pp. 2032-2040. ISSN: 2040-7459; e-ISSN: 2040-7467.

[22] Rosenblum M and Garfinkel T. "Virtual machine monitors: current technology and future trends". In: IEEE Computer Society, 2005, pp. 39-47. URL: http://dx.doi. org/10.1109/MC.2005.176.

[23] Veldkamp A and Verburg P. "Modelling land use change and environmental impact". In: Journal of Environmental Management, 2004. URL: http://dx.doi.org/10.1016/j . jenvman.2004.04.004.

[24] Victor T and Jiangfeng Li. "Analysis of Land Use and Land Cover Changes, and Their Ecological Implications in Wuhan, China". In: Journal of Geography and Geology Vol. 3, No. 1 (September 2011).

[25] Vitousek P et al. "Human dominated Earth's ecosystems" In: Science, 277(5325), 1997, pp. 494-499. URL: http://dx.doi.org/10.1126/science.277.5325.494.

[26] Trimble S and Crosson P. "Land use: U.S. soil erosion rates". In: Myth and reality Science, 289, 2000, pp. 248-250. URL: http://dx.doi.org/10.1126/science.289. 5477.248. 
